\author{
Iwona Kopacz \\ Zakład Geografii Społecznej \\ Instytut Geografii \\ Uniwersytet Humanistyczno-Przyrodniczy Jana Kochanowskiego w Kielcach
}

\title{
Rozwój przedsiębiorczości w strefie podmiejskiej Kielc w warunkach transformacji gospodarczej
}

Transformacja systemowa zapoczątkowana w Polsce pod koniec lat 80 . XX w. pociągnęła za sobą wiele zmian gospodarczych, społecznych i kulturowych, zarówno na wsi, jak i w miastach. Są one kształtowane przez różnorodne procesy i zjawiska, a do najważniejszych z nich należą (Maik 1997):

1. zmiany politycznego ustroju państwa;

2. przejście od gospodarki centralnie sterowanej do gospodarki rynkowej;

3. zagwarantowanie równoprawności podmiotów gospodarczych wobec prawa i instytucji państwa;

4. zmieniające się proporcje własności środków produkcji;

5. nowe stosunki pracy.

Okres ostatnich kilkunastu lat jest niepowtarzalny, przede wszystkim ze względu na zmianę systemu politycznego i ekonomicznego oraz wejście Polski do Unii Europejskiej. Proces przejścia do gospodarki rynkowej i systemu samorządowego spowodował radykalne zmiany w funkcjonowaniu systemów osadniczych. Zmieniły się zasady i mechanizmy rozwoju miast, czynniki lokalizacji i kryteria efektywności gospodarki miejskiej. W miastach zaczęły występować nowe zjawiska, zarówno w sferze gospodarczej, jak i społecznej, związane ze zmianą struktury własnościowej podmiotów gospodarczych, przywróceniem reguł rynkowych i redukcją funkcji opiekuńczych państwa.

Złożony proces transformacji ustrojowej ujawnił słabość większości podmiotów gospodarczych. Objawiało się to przede wszystkim obniżeniem ich aktywności gospodarczej i trudnościami w gospodarowaniu. Zmieniające się warunki działalności gospodarczej, a w szczególności swoboda tworzenia nowych jednostek na równych prawach z dotychczas funkcjonującymi, sprzyjały odradzaniu się w Polsce przedsiębiorczości.

Celem niniejszego artykułu jest analiza zmian w rozwoju przedsiębiorczości, jakie zaszły na terenach podmiejskich Kielc po 1989 r., z uwzględnieniem poszczególnych sekcji działalności gospodarczej.

Badaniem objęto 8 gmin bezpośrednio graniczących z miastem Kielce (pierścień A) oraz 14 gmin otaczających (pierścień B). Zakres czasowy to lata 1995-2005.

Jednym z podstawowych wskaźników określających aktywność gospodarczą ludności danego obszaru jest wskaźnik przedsiębiorczości, obrazujący liczbę podmiotów gospodarczych danej jednostki terytorialnej na 1000 osób w wieku produkcyjnym. W celu porównania przedsiębiorczości w poszczególnych sektorach gospodarki narodowej oraz w poszczególnych gminach, wyliczono wskaźnik przedsiębiorczości dla sektorów: rolnictwa, przemysłu i usług. 
Do obliczenia wskaźnika przedsiębiorczości dla sektora rolnictwa wzięto pod uwagę podmioty gospodarcze zarejestrowane w REGON w sekcjach A i B, czyli odpowiadającym sektorowi rolnictwa. Analogicznie postąpiono, obliczając wskaźnik przedsiębiorczości dla sektora przemysłu (sekcje C-F) oraz sektora usług (pozostałe sekcje - własność prywatna).

\section{Strefa podmiejska, przedsiębiorczość - problemy definicji}

Definiując pojęcie ,przedsiębiorczość”, można brać pod uwagę różne aspekty. Jest to przede wszystkim cecha charakteru, postawa człowieka, która wyraża się w jego twórczym działaniu, zmierzającym do zapewnienia racjonalnej i efektywnej koordynacji zasobów gospodarczych, umożliwiająca osiąganie racjonalności gospodarowania i efektywności ekonomicznej. K. Jaremczuk (2003) definiuje przedsiębiorczość jako określoną siłę społeczno-ekonomiczną o wymiarze ekonomicznym, ale również osobowym, społecznym i kulturowym.

W teorii ekonomii przedsiębiorczość definiowana jest jako swoista forma pracy lub jako czwarty (obok pracy, ziemi i kapitału) czynnik produkcji. Główne cechy przedsiębiorców to: umiejętność dostrzegania potrzeb i doskonalenia pomysłów, zdolność do wykorzystywania nadarzających się okazji oraz gotowość do podejmowania ryzyka.

Zdaniem L. Kaliszczak (2002), przedsiębiorczość oznacza ,proces identyfikacji i wykorzystania szans, niezależnie od aktualnie posiadanych zasobów materialnych". Zdaniem J. Targalskiego (1999), przedsiębiorczość to ,zdolność do tego, żeby być przedsiębiorczym, posiadanie ducha inicjatywy, obrotność, rzutkość, zaradność”. Autor ten stwierdza również, że ,zgodnie z nowoczesnymi koncepcjami przedsiębiorczość traktowana jest jako proces inicjowania i wprowadzania zmian, zanikający okresowo do czasu pojawienia się nowych inicjatyw. Jest to proces tworzenia czegoś nowego i wartościowego, z założeniem osobistego ryzyka finansowego, ale także z założeniem rekompensaty pieniężnej lub osobistej satysfakcji”.

Reasumując, przedsiębiorczość można określić jako proces tworzenia i rozwoju działalności gospodarczej, nacechowany ryzykiem i niepewnością działania, zmierzający do realizacji zamierzonych celów przedsiębiorcy. W ujęciu procesowym przedsiębiorczość składa się z poszukiwania informacji i rozpoznawania szans oraz nabywania zasobów i kształtowania strategii firmy. Przedsiębiorczość może być realizowana z różną intensywnością, a jej wymiarami są: poziom innowacyjności, poziom ryzyka gospodarczego i poziom aktywności. Dzięki temu możliwe jest ujęcie jej zmiennej natury (Lichtarski 2003).

Duże znaczenie w prezentowanej pracy ma również sprecyzowanie pojęcia „strefa podmiejska". Definicja ta w ciągu ostatnich kilkudziesięciu lat ulegała ewolucji. Jednym z podstawowych problemów utrudniających zdefiniowanie tego terminu jest fakt, że nie ma spójnej, uniwersalnej definicji miasta, która określałaby jego zasięg i granice. Stąd m.in. trudności ze zdefiniowaniem strefy, która je bezpośrednio otacza (Straszewicz 1985).

Jak twierdzi J. Jurek (1991), termin „strefa podmiejska” wprowadzony został dla potrzeb planowania. W definicjach „strefy podmiejskiej” w latach 80. XX w. podkreśla się, że jest ona zjawiskiem zmiennym w czasie i przestrzeni, że wraz z rozwojem miasta zmieniają się jej związki z obszarem otaczającym, a tym samym i funkcje strefy podmiejskiej (Maik 1985), stanowi przedłużenie społeczne i przestrzenne samego miasta (Rakowski 1985) i jest indukowana sąsiedztwem miasta i jego przemianami (Dziewoński 1987). Według socjologów (Ziemilski, Skórzyński 1983), strefa podmiejska jest tym, co ludzie zwykli za taką strefę uważać (pojmowanie socjokulturowe) lub szczególnie wyróżnionym i wyodrębnionym obszarem wokół miasta (pojmowanie topograficzne). M. Koter (1985) za strefę podmiejską uważa obszar żywych, wielostronnych i bezpośrednich kontaktów z miastem, pas terenu 
otaczający ośrodek centralny, w obrębie którego zachodzi przenikanie się form życia miejskiego i wiejskiego, przy czym wpływ miasta jest czynnikiem decydującym. Z przytoczonymi wyżej poglądami polemizuje A. Suliborski (1985), podkreślając, że o tym, czy dany obszar jest strefą podmiejską, świadczy natężenie funkcji podmiejskich, a nie stopień zaawansowania procesów urbanizacyjnych. Według A. Jelonka (1985), każde miasto wytwarza wokół siebie strefę podmiejską, która ma specyficzne funkcje w zakresie użytkowania ziemi i cech demograficznych. Strefy podmiejskie nie muszą mieć ciągłości terytorialnej; mogą przybierać różne kształty geometryczne; pod względem struktury funkcjonalnej mogą je charakteryzować wszystkie funkcje, tylko niektóre lub jedna.

Generalnie za strefę podmiejską powszechnie uważa się obszar położony w bezpośrednim sąsiedztwie miasta, powiązany z nim i systematycznie przekształcany (Liszewski 1985). Określa się ją też jako obszar przejściowy między wsią a miastem, głównie w płaszczyźnie przestrzennej (mieszane formy zagospodarowania przestrzeni i przejściowe typy osadnictwa). Można jednak podać kilka charakterystycznych cech, którymi strefa podmiejska się wyróżnia (Straszewicz 1985; Maik 1985):

- jest związana $\mathrm{z}$ miastem w taki sposób, że tworzą razem jeden system; jest integralną częścią systemu miejskiego;

- powiązania strefy z miastem mają charakter przestrzenny (wynikający z położenia) i funkcjonalny;

- rozwija się dzięki wpływom miasta, zmienia się wraz z rozwojem i przekształceniami strukturalnymi miasta;

- spełnia określone funkcje, bez których miasto nie mogłoby się należycie rozwijać lub nawet istnieć;

- występują w niej miasta i osiedla satelitarne, zamieszkane przez ludzi pracujących i uczących się w mieście.

W nowszych opracowaniach (Misiak 1992) stwierdza się, że jakkolwiek strefa podmiejska ma pewne cechy specyficzne tylko dla niej, to nie stanowi wyizolowanego obszaru o wyraźnie i jednoznacznie określonych granicach. J. Rajman (2000) określa ją jako zorganizowaną część przestrzeni geograficznej, która przylega do terenów zainwestowanych miasta centralnego. Autorka podziela najnowsze poglady na temat strefy podmiejskiej; uważa, że strefa podmiejska to obszar leżący pomiędzy miastem centralnym (macierzystym) a terenami tradycyjnie wiejskimi, komplementarnie z tym miastem powiązany, ulegający ciągłym przeobrażeniom pod jego wpływem i spełniający specyficzne funkcje, zmieniające się zarówno w czasie, jak i w przestrzeni, aby dostosowywać je do rozwijającego się miasta macierzystego. Ponadto, na obszarze strefy podmiejskiej obserwuje się nasilenie procesów urbanizacyjnych, prowadzących do zanikania tradycyjnego krajobrazu wiejskiego oraz przenikania się form życia miejskiego i wiejskiego.

\section{Działalność gospodarcza w strefie podmiejskiej Kielc w 1995 r.}

W 1995 r. w strefie podmiejskiej Kielc funkcjonowały 5554 podmioty gospodarcze (tab. 1). Stanowiło to 93,8 \% ogółu podmiotów funkcjonujących na tym obszarze (łącznie z sektorem publicznym).

W strukturze analizowanych jednostek gospodarczych największe znaczenie miały podmioty usługowe. W 1995 r. na badanym obszarze było ich 3981, czyli 71,7\% ogólnej liczby badanych podmiotów. Drugą pozycję zajmowały podmioty związane z przemysłem: w $1995 \mathrm{r}$. było ich 1435 , czyli $25,8 \%$. Najmniejsze znaczenie miały podmioty związane z rolnictwem. W 1995 r. zarejestrowanych było 138 podmiotów, co stanowiło 2,5\% ogółu. 
Tab. 1. Podmioty gospodarcze sektora prywatnego w strefie podmiejskiej Kielc w $1995 \mathrm{r}$.

\begin{tabular}{|l|c|c|c|c|c|c|c|}
\hline \multirow{2}{*}{$\begin{array}{l}\text { Wyszcze- } \\
\text { gólnienie }\end{array}$} & \multirow{2}{*}{ ogólem } & \multicolumn{3}{|c|}{ w tym } & \multicolumn{3}{|c|}{$\begin{array}{c}\text { Struktura podmiotów } \\
\text { gospodarczych (w \%) }\end{array}$} \\
\cline { 2 - 8 } & & przemysł & usługi & rolnictwo & przemysł & usługi & rolnictwo \\
\hline Pierścień A & 2750 & 811 & 1878 & 61 & 29,5 & 68,3 & 2,2 \\
\hline Pierścień B & 2804 & 624 & 2103 & 77 & 22,3 & 75,0 & 2,7 \\
\hline Razem & $\mathbf{5 5 5 4}$ & $\mathbf{1 4 3 5}$ & $\mathbf{3 9 8 1}$ & $\mathbf{1 3 8}$ & $\mathbf{2 5 , 8}$ & $\mathbf{7 1 , 7}$ & $\mathbf{2 , 5}$ \\
\hline
\end{tabular}

Źródło: opracowanie autorki na podstawie www.stat.gov.pl

Tab. 2. Wskaźnik przedsiębiorczości w strefie podmiejskiej Kielc w 1995 r.

\begin{tabular}{|c|c|l|l|}
\hline $\begin{array}{c}\text { Wskaźnik } \\
\text { przedsiębiorczości }\end{array}$ & Liczba gmin & \multicolumn{2}{|c|}{ Gminy } \\
\hline \multirow{2}{*}{ do 45} & 11 & Pierścień A & Górno, Piekoszów \\
\cline { 3 - 4 } & \multirow{2}{*}{$45,1-60,0$} & Pierścień B & $\begin{array}{l}\text { Bieliny, Małogoszcz, Bodzentyn, Mniów, } \\
\text { Strawczyn, Lączna, Pierzchnica, Sobków, Kije }\end{array}$ \\
\hline \multirow{2}{*}{$60,1-90,0$} & 9 & Pierścień A & Miedziana Góra, Chęciny, Morawica, Masłów \\
\cline { 3 - 4 } & Pierścień B & Zagnańsk, Raków, Lagów, Chmielnik, Łopuszno \\
\hline \multirow{2}{*}{2} & Pierścień A & Daleszyce, Sitkówka-Nowiny \\
\cline { 2 - 4 } & & Pierścień B & - \\
\hline
\end{tabular}

Źródło: opracowanie autorki na podstawie www.stat.gov.pl

Średni wskaźnik przedsiębiorczości wynosił 48,8, a w poszczególnych gminach był bardzo zróżnicowany (tab. 2). W 1995 r. wahał się od 27,7 do 74,7 (tab. 3, ryc. 1). Najwyższe wartości przyjął w dwóch gminach: Sitkówka-Nowiny $(74,7)$ i Daleszyce $(71,6)$; obie należą do pierścienia A. Drugą grupę tworzyły gminy, w których wskaźnik mieścił się w granicach 45,1-60. Było to dziewięć gmin, z których cztery leżą w granicach pierścienia A (Morawica, Chęciny, Masłów, Miedziana Góra), a pięć - w granicach pierścienia B (Zagnańsk, Łopuszno, Chmielnik, Łagów, Raków). Ostatnią grupę stanowiło jedenaście gmin, w których wskaźnik przedsiębiorczości przyjmował wartości poniżej 45,0. Najniższą wartość odnotowano w gminie Kije: 27,7. Inaczej przedstawia się sytuacja w poszczególnych sektorach gospodarki narodowej.

Tab. 3. Wskaźnik przedsiębiorczości w strefie podmiejskiej Kielc według sektorów w 1995 r.

\begin{tabular}{|l|c|c|c|}
\hline \multirow{2}{*}{ Gmina } & \multicolumn{3}{|c|}{ Wskaźnik przedsiębiorczości dla sektora } \\
\cline { 2 - 4 } & rolnictwa & przemysłu & usług \\
\hline Chęciny & 1,5 & 16,1 & 39,5 \\
\hline Daleszyce & 2,0 & 17,2 & 52,4 \\
\hline Górno & 0,8 & 15,2 & 28,9 \\
\hline Masłów & 1,2 & 16,8 & 34,7 \\
\hline Miedziana Góra & 0,8 & 21,3 & 35,4 \\
\hline Morawica & 1,7 & 14,8 & 38,4 \\
\hline
\end{tabular}




\begin{tabular}{|l|c|c|c|}
\hline \multirow{2}{*}{ Gmina } & \multicolumn{3}{|c|}{ Wskaźnik przedsiębiorczości dla sektora } \\
\cline { 2 - 4 } & rolnictwa & przemysłu & usług \\
\hline Piekoszów & 0,6 & 10,5 & 26,7 \\
\hline Sitkówka-Nowiny & 0,6 & 24,7 & 49,4 \\
\hline Bieliny & 0,2 & 6,0 & 35,5 \\
\hline Bodzentyn & 0,3 & 7,2 & 31,8 \\
\hline Chmielnik & 0,9 & 9,3 & 42,7 \\
\hline Kije & 0,8 & 4,7 & 22,2 \\
\hline Lagów & 0,5 & 8,9 & 44,9 \\
\hline Lączna & 1,0 & 6,4 & 24,6 \\
\hline Lopuszno & 3,2 & 11,1 & 34,5 \\
\hline Małogoszcz & 1,2 & 10,3 & 28,1 \\
\hline Mniów & 1,3 & 7,5 & 25,7 \\
\hline Pierzchnica & 1,6 & 6,8 & 20,9 \\
\hline Raków & 0,6 & 7,7 & 47,0 \\
\hline Sobków & 0,7 & 8,2 & 20,4 \\
\hline Strawczyn & 1,4 & 10,6 & 21,5 \\
\hline Zagnańsk & 2,3 & 18,9 & 37,5 \\
\hline
\end{tabular}

Źródło: opracowanie autorki na podstawie www.stat.gov.pl

Najwyższe wartości wskaźnik przedsiębiorczości przyjął w sektorze usług. Wahał się od 20,4 do 52,4 (tab. 3, ryc. 1), a jego średnia wartość w 1995 r. wyniosła 34,7. Najwyższe wartości przyjął w grupie pięciu gmin: Daleszyce $(52,4)$, Sitkówka-Nowiny $(49,4)$, Raków $(47,0)$, Łagów $(44,9)$ i Chmielnik $(42,7)$. Dwie pierwsze leżą w granicach pierścienia A, a trzy pozostałe - w granicach pierścienia B. Drugą grupę tworzyły gminy, w których wskaźnik wahał się od 29,1 do 40,0. Takich gmin było osiem; cztery z nich (Chęciny, Masłów, Miedziana Góra, Morawica) należą do pierścienia A, cztery kolejne (Bieliny, Bodzentyn, Łopuszno, Zagnańsk) - do pierścienia B. W dziewięciu pozostałych gminach wskaźnik przedsiębiorczości dla sektora usług przyjął najniższe wartości - poniżej 29,0.

Bardzo zróżnicowany w układzie przestrzennym był wskaźnik przedsiębiorczości w sektorze przemysłu; jego średnia wartość w 1995 r. w strefie podmiejskiej Kielc wynosiła 12,9. W poszczególnych gminach wahał się on od 4,7 do 24,7 (tab. 3, ryc. 1). Najwyższe wartości przyjął w grupie siedmiu gmin, spośród których aż sześć należy do pierścienia A (Sitkówka-Nowiny, Miedziana Góra, Daleszyce, Masłów Chęciny, Górno), a tylko jedna - Zagnańsk - leży w granicach pierścienia B. W grupie drugiej wartości wskaźnika wahały się w granicach 10,1-15,0; znalazły się w niej dwie gminy pierścienia A (Morawica i Piekoszów) oraz trzy gminy pierścienia B (Łopuszno, Małogoszcz, Strawczyn). Trzecią grupę stanowiły gminy, w których wskaźnik przybrał wartości poniżej 10,0. Tworzyło ją dziesięć gmin.

Wskaźnik przedsiębiorczości w sektorze rolnictwa w strefie podmiejskiej Kielc w 1995 r. miał najniższe wartości wśród wszystkich analizowanych wskaźników. Wahały się one w granicach 0,2 -3,2 (tab. 3, ryc. 1), a średnia jego wartość wyniosła 1,15. Najwyższe 
wartości wskaźnika wystąpiły w dwóch gminach należących do pierścienia B (Łopuszno, Zagnańsk). Drugą grupę stanowią gminy, w których wartość wskaźnika wahała się w granicach 1,1-2,0. W 1995 r. takich gmin było osiem; cztery z nich leżą w pierścieniu A (Chęciny, Daleszyce, Masłów, Morawica), a cztery pozostałe - w pierścieniu B (Małogoszcz, Mniów, Pierzchnica, Strawczyn). W pozostałych gminach wskaźnik przyjął wartości poniżej 1,0. Grupę tę tworzyło dwanaście gmin.

Ryc. 1. Wskaźnik przedsiębiorczości w gminach pierścieni A i B w 1995 r.
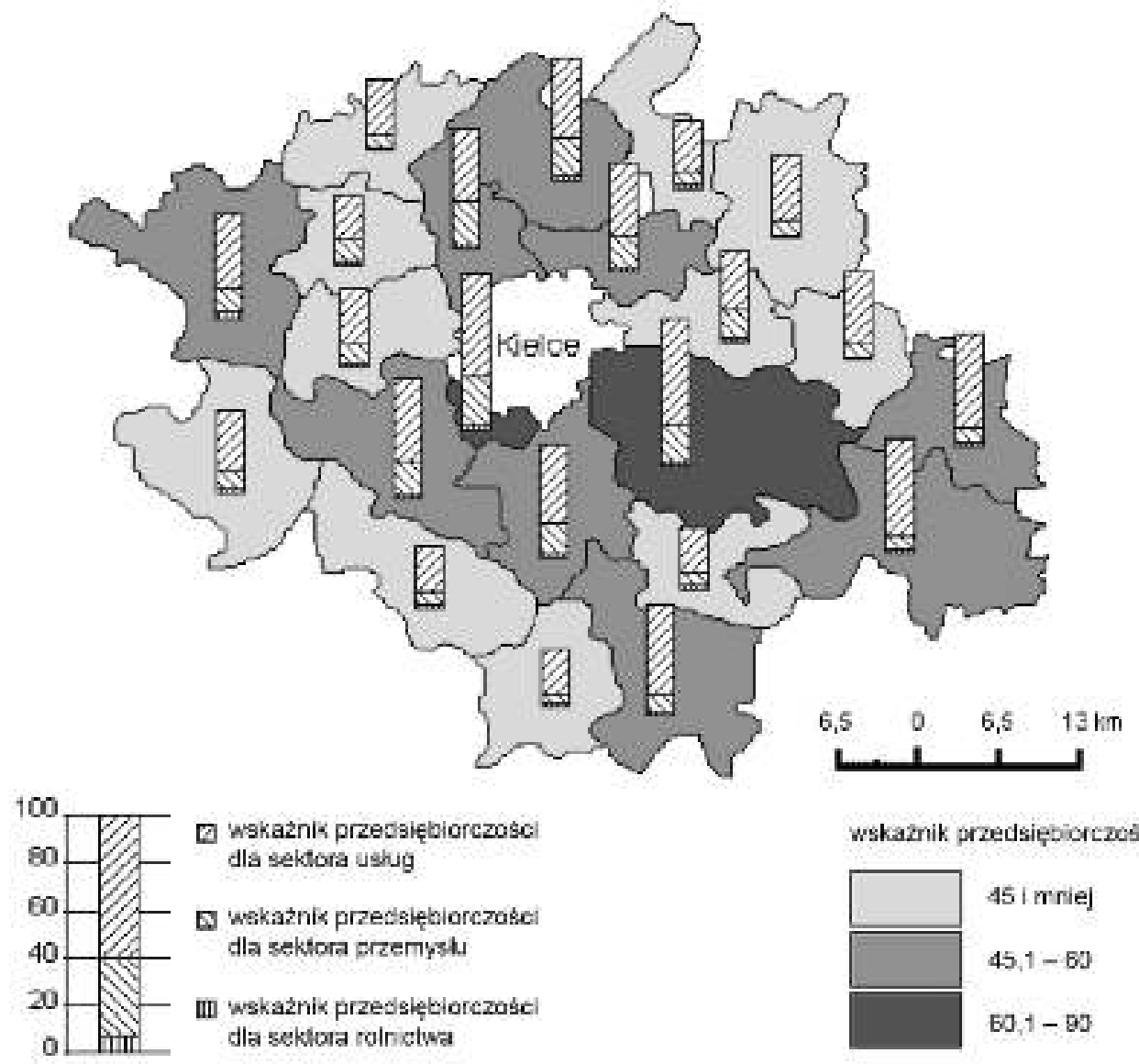

wskaznik przedsiębicrczoslci

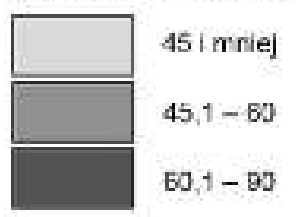

Źródło: opracowanie autorki na podstawie www.stat.gov.pl

Działalność gospodarcza w strefie podmiejskiej Kielc w 2005 r.

W 2005 r. w strefie podmiejskiej Kielc funkcjonowały 12493 podmioty gospodarcze (tab. 4), czyli 96,3\% ogółu działających na tym obszarze jednostek zarejestrowanych w rejestrze REGON (łącznie z sektorem publicznym). Liczba zarejestrowanych jednostek w stosunku do roku 1995 wzrosła ponaddwukrotnie.

Tab. 4. Podmioty gospodarcze sektora prywatnego w strefie podmiejskiej Kielc w 2005 r.

\begin{tabular}{|l|c|c|c|c|c|c|c|}
\hline \multirow{2}{*}{$\begin{array}{l}\text { Wyszcze- } \\
\text { gólnienie }\end{array}$} & \multirow{2}{*}{ ogółem } & \multicolumn{3}{|c|}{ w tym } & \multicolumn{3}{c|}{$\begin{array}{c}\text { Struktura podmiotów } \\
\text { gospodarczych (w \%) }\end{array}$} \\
\cline { 2 - 8 } & & przemysł & usługi & rolnictwo & przemysł & usługi & rolnictwo \\
\hline Pierścień A & 6229 & 1599 & 4476 & 154 & 25,7 & 71,8 & 2,5 \\
\hline Pierścień B & 6264 & 1485 & 4546 & 233 & 23,7 & 72,6 & 3,7 \\
\hline Razem & $\mathbf{1 2 4 9 3}$ & $\mathbf{3 0 8 4}$ & $\mathbf{9 0 2 2}$ & $\mathbf{3 8 7}$ & $\mathbf{2 4 , 7}$ & $\mathbf{7 2 , 2}$ & $\mathbf{3 , 1}$ \\
\hline
\end{tabular}

Źródło: opracowanie autorki na podstawie www.stat.gov.pl 
W strukturze analizowanych jednostek gospodarczych największe znaczenie miały podmioty usługowe, których w 2005 r. na badanym obszarze było 9022, czyli 72,2 \% ogólnej liczby badanych podmiotów. W stosunku do $1995 \mathrm{r}$. oznacza to wzrost o 0,5 pp. Drugą pozycję zajmowały podmioty związane z przemysłem: w 2005 r. było ich 3084, czyli 24,7\% ogółu (w 1995 r. 25,8\%). Najmniejsze znaczenie, podobnie jak w roku 1995, miały podmioty związane z rolnictwem: w 2005 r. zarejestrowanych było 387 jednostek, czyli 3,1\% ogółu analizowanych podmiotów (wzrost o $0,6 \%$ ).

W latach 1995-2005 wskaźnik przedsiębiorczości wzrósł we wszystkich gminach. W 2005 r. wyniósł 94,5. W poszczególnych jednostkach przestrzennych wahał się od 62,1 do 134,1 (tab. 6, ryc. 2). Najwyższe wartości przyjął w trzech gminach pierścienia A: Sitkówka-Nowiny $(134,1)$, Masłów $(118,2)$ oraz Miedziana Góra $(116,9)$. W stosunku do 1995 r. tylko gmina Sitkówka-Nowiny utrzymała przewagę. Liczba podmiotów gospodarczych sektora prywatnego wzrosła z 275 do 606, czyli o 120\%. Wysokie tempo wzrostu liczby prywatnych podmiotów gospodarczych w gminach Masłów i Miedziana Góra spowodowało, że pod względem wskaźnika przedsiębiorczości znalazły się one w grupie najwyższych wartości, obok gminy Sitkówki-Nowiny. Drugą grupę tworzyły gminy, w których wskaźnik wahał się w granicach 90,1-115,0 (tab. 5). W 2005 r. tworzyło ją dziewięć gmin, z których trzy leżą w granicach pierścienia A (Chęciny, Morawica, Daleszyce), a sześć - w granicach pierścienia B (Zagnańsk, Raków, Chmielnik, Sobków, Małogoszcz, Łopuszno). Ostatnia grupa to gminy, w których wskaźnik przedsiębiorczości przyjął wartości poniżej 90,0 - są to pozostałe gminy pierścienia A i B. Najniższą wartość odnotowano w gminie Bodzentyn - 62,1. Należy dodać, że wartości wskaźnika przedsiębiorczości systematycznie rosły w analizowanym okresie. Największy wzrost - o 65,5 - zaobserwowano w gminie Masłów; wskaźnik wzrósł z 52,7 w 1995 r. do 116,9 w 2005 r.

Tab. 5. Wskaźnik przedsiębiorczości w strefie podmiejskiej Kielc w 2005 r.

\begin{tabular}{|c|c|l|l|}
\hline \multirow{2}{*}{ Przedzial } & Liczba gmin & \multicolumn{2}{|c|}{ Gminy } \\
\hline \multirow{2}{*}{$60,1-90,0$} & 10 & Pierścień A & Górno, Piekoszów \\
\cline { 3 - 4 } & \multirow{2}{*}{$90,1-115,0$} & Pierścień B & $\begin{array}{l}\text { Strawczyn, Łagów, Pierzchnica, Łączna, Bieliny, } \\
\text { Kije, Mniów, Bodzentyn }\end{array}$ \\
\hline \multirow{2}{*}{115,1 i więcej } & \multirow{2}{*}{3} & Pierścień A & Morawica, Daleszyce, Chęciny \\
\cline { 3 - 4 } & Pierścień B & $\begin{array}{l}\text { Zagnańsk, Małogoszcz, Chmielnik, Raków, } \\
\text { Łopuszno, Sobków }\end{array}$ \\
\cline { 3 - 4 } & & Pierścień A & Sitkówka-Nowiny, Masłów, Miedziana Góra \\
\cline { 2 - 4 } & Pierścień B & - \\
\hline
\end{tabular}

Źródło: opracowanie autorki na podstawie www.stat.gov.pl

A oto sytuacja w poszczególnych sektorach gospodarki narodowej. Najwyższe wartości, podobnie jak w 1995 r., przyjmował wskaźnik przedsiębiorczości liczony dla sektora usług. Wahał się on od 44,2 do 95,6 (tab. 6, ryc. 2), a jego średnia wartość w 2005 r. wyniosła 68,1 (w 1995 r. - 34,7). Najwyższe wartości przyjął w grupie czterech gmin, z których trzy należą do pierścienia A: Sitkówka-Nowiny $(95,6)$, Morawica $(82,2)$, Masłów $(81,6)$, a jedna należy do pierścienia B: Chmielnik $(82,6)$. Drugą grupę tworzyły gminy, w których wskaźnik wahał się od 60,1 do 80,0. Trzy z nich: Chęciny, Daleszyce i Miedziana Góra, leżą w pierścieniu A, 
a sześć: Łagów, Łopuszno, Małogoszcz, Raków, Sobków i Zagnańsk, w pierścieniu B. W pozostałych gminach wskaźnik przedsiębiorczości dla sektora usług przyjmował wartości poniżej 60,0. Grupę tę tworzyło dziewięć gmin. Należy dodać, że wskaźnik przedsiębiorczości sektora usług rósł systematycznie $\mathrm{w}$ analizowanym okresie, a największy wzrost zaobserwowano w gminie Masłów, gdzie z 34,7 w 1995 r. wzrósł o 46,9 i w 2005 r. osiągnął wartość 81,6.

Tab. 6. Wskaźnik przedsiębiorczości w strefie podmiejskiej Kielc według sektorów w 2005 r.

\begin{tabular}{|c|c|c|c|}
\hline \multirow{2}{*}{ Gmina } & \multicolumn{3}{|c|}{ Wskaźnik przedsiębiorczości dla sektora } \\
\hline & rolnictwa & przemysłu & usług \\
\hline Chęciny & 2,9 & 20,9 & 68,6 \\
\hline Daleszyce & 4,1 & 20,9 & 74,1 \\
\hline Górno & 1,6 & 24,5 & 59,7 \\
\hline Masłów & 3,3 & 33,3 & 81,6 \\
\hline Miedziana Góra & 3,4 & 33,7 & 79,8 \\
\hline Morawica & 2,1 & 27,9 & 82,2 \\
\hline Piekoszów & 1,4 & 20,9 & 58,7 \\
\hline Sitkówka-Nowiny & 1,1 & 37,4 & 95,6 \\
\hline Bieliny & 2,2 & 13,9 & 57,1 \\
\hline Bodzentyn & 1,5 & 13,8 & 46,8 \\
\hline Chmielnik & 2,2 & 14,0 & 82,6 \\
\hline Kije & 1,9 & 19,6 & 46,2 \\
\hline Łagów & 3,7 & 11,4 & 65,9 \\
\hline Łączna & 4,7 & 16,1 & 53,3 \\
\hline Łopuszno & 5,1 & 23,6 & 65,8 \\
\hline Małogoszcz & 3,3 & 29,3 & 68,0 \\
\hline Mniów & 3,4 & 18,4 & 44,2 \\
\hline Pierzchnica & 3,3 & 15,7 & 55,8 \\
\hline Raków & 3,0 & 18,5 & 76,5 \\
\hline Sobków & 4,3 & 25,5 & 62,3 \\
\hline Strawczyn & 2,5 & 25,4 & 57,0 \\
\hline Zagnańsk & 4,3 & 29,1 & 73,7 \\
\hline
\end{tabular}

Źródło: opracowanie autorki na podstawie www.stat.gov.pl

Średnia wartość wskaźnika przedsiębiorczości dla sektora przemysłu w strefie podmiejskiej Kielc w 2005 r. wynosiła 23,5. W poszczególnych gminach wahał się on od 11,4 do 37,4 (tab. 6, ryc. 2). Najwyższe wartości przyjął w grupie trzech gmin należących do pierścienia A: Sitkówka-Nowiny, Miedziana Góra i Masłów. Drugą grupę stanowiły gminy, w których wartości wskaźnika wahały się granicach 20,1-30,0. Należy do niej pięć gmin pierścienia A (Chęciny, 
Daleszyce, Górno, Morawica, Piekoszów) oraz pięć gmin pierścienia B (Łopuszno, Małogoszcz, Sobków, Strawczyn, Zagnańsk). Trzecią grupę stanowiło dziewięć gmin pierścienia B, w których wskaźnik przyjmował wartości poniżej 20,0. Wartości wskaźnika przedsiębiorczości dla sektora przemysłu również systematycznie rosły. Największy wzrost odnotowano w gminie Małogoszcz - z 10,3 do 29,3 w 2005 r., czyli o 19,0 pp.

Ryc. 2. Wskaźnik przedsiębiorczości w gminach pierścieni A i B w 2005 r.

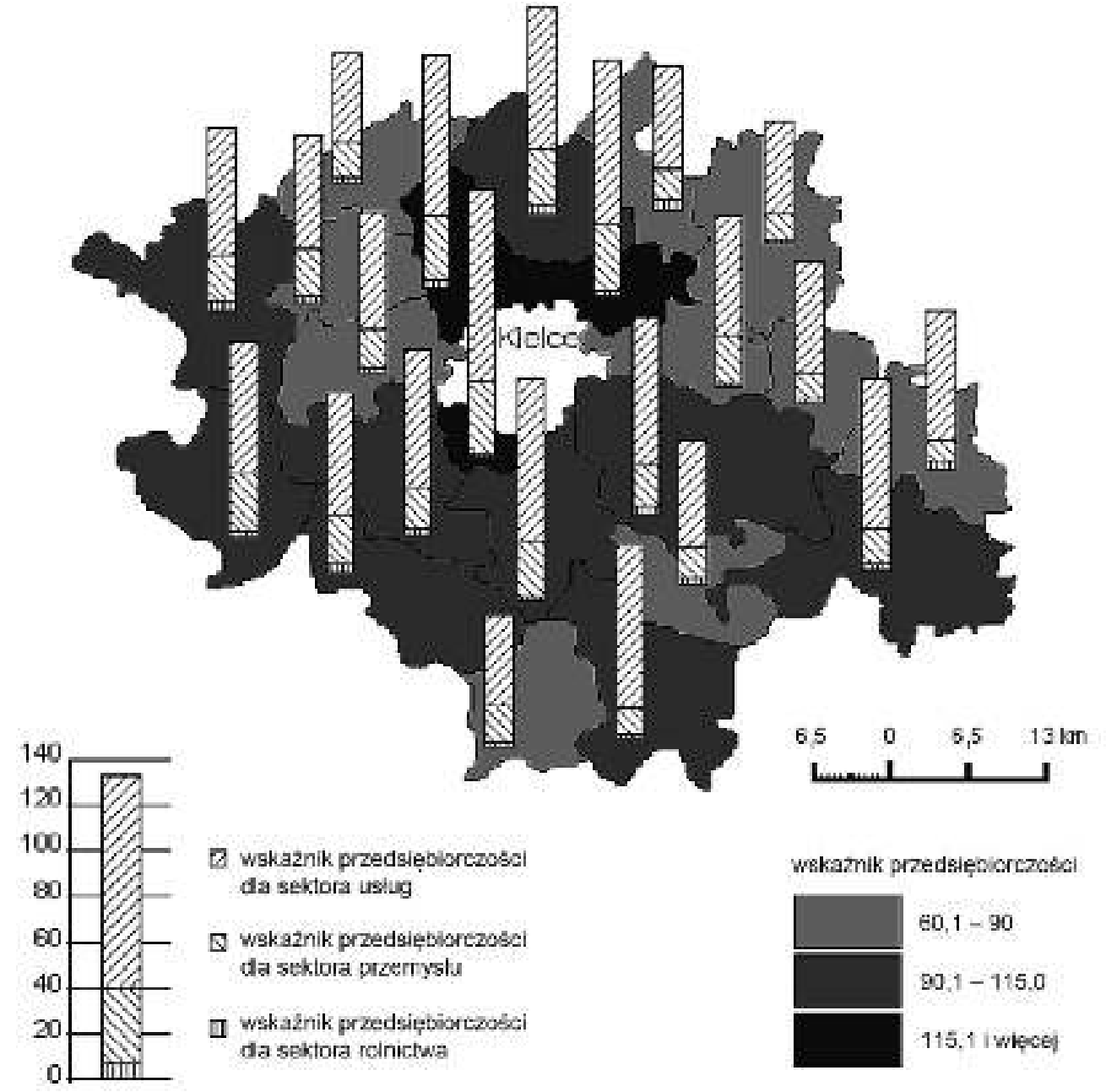

Źródło: opracowanie autorki na podstawie www.stat.gov.pl

Wskaźnik przedsiębiorczości dla sektora rolnictwa w strefie podmiejskiej Kielc w 2005 r. osiągał (podobnie jak 10 lat wcześniej) najniższe wartości spośród wszystkich analizowanych wskaźników. Wahały się one w granicach 1,1-5,1 (tab. 6, ryc. 2), a średnia wartość wyniosła 2,9. Najwyższe wartości wystąpiły $\mathrm{w}$ grupie pięciu gmin, $\mathrm{z}$ których jedna należy do pierścienia A (Daleszyce), a cztery pozostałe (Łopuszno, Łączna, Sobków, Zagnańsk) - do pierścienia B. Drugą grupę stanowiło sześć gmin, w których wartości wskaźnika wahały się w granicach 3,1-4,0. Dwie z nich leżą w pierścieniu A (Miedziana Góra i Masłów), cztery pozostałe (Łagów, Małogoszcz, Mniów, Pierzchnica) - w pierścieniu B. W pozostałych gminach wskaźnik przyjmował wartości poniżej 3,0. Grupę tę tworzyło jedenaście gmin. Wartości wskaźnika przedsiębiorczości dla sektora rolnictwa wzrosły nieznacznie w stosunku do roku 1995. Największy wzrost odnotowano w gminie Łączna, w której wskaźnik wzrósł o 3,7 - z 1,0 w 1995 r. do 4,7 w 2005 r. 


\section{Zmiany wskaźnika przedsiębiorczości w ujęciu sektorowym w strefie podmiejskiej Kielc w latach 1995-2005}

W celu scharakteryzowania zmian wskaźnika przedsiębiorczości w ujęciu sektorowym w strefie podmiejskiej Kielc w latach 1995-2005, obliczono wartość średnią, odpowiednio dla wszystkich gmin pierścienia $A$ oraz wszystkich gmin pierścienia $\mathrm{B}$, dotyczące wskaźnika przedsiębiorczości oraz wskaźników przedsiębiorczości dla sektora: rolnictwa, przemysłu i usług dla lat 1995 i 2005 (tab. 7).

Tab. 7. Wskaźnik przedsiębiorczości w gminach pierścieni A i B w latach 1995 i 2005

\begin{tabular}{|c|c|c|c|c|c|}
\hline \multirow{2}{*}{ Rok } & \multirow{2}{*}{ Obszar } & \multicolumn{4}{|c|}{ Wskaźnik przedsiębiorczości } \\
\cline { 3 - 6 } & & \multirow{2}{*}{ ogólem } & \multicolumn{3}{|c|}{ dla sektora } \\
\cline { 3 - 6 } & & & rolnictwa & przemysłu & usług \\
\hline \multirow{2}{*}{1995} & gminy pierścienia A & 56,4 & 1,1 & 17,1 & 38,2 \\
\cline { 3 - 6 } & gminy pierścienia B & 41,2 & 1,2 & 8,8 & 31,2 \\
\hline \multirow{2}{*}{2005} & gminy pierścienia A & 105,0 & 2,5 & 27,4 & 75,0 \\
\cline { 3 - 6 } & gminy pierścienia B & 83,9 & 3,2 & 19,6 & 61,1 \\
\hline
\end{tabular}

Źródło: opracowanie autorki na podstawie www.stat.gov.pl

W latach 1995-2005 we wszystkich gminach pierścienia A wskaźnik przedsiębiorczości (ogółem) wzrósł z 56,4 do 105,0, czyli o 48,6 (tab. 7, ryc. 3). Wskaźnik przedsiębiorczości dla sektora usług również rósł systematycznie, z 38,2 do 75,0, czyli o 36,8. Analizując poziom przedsiębiorczości według sekcji PKD zaobserwowano, że we wszystkich gminach pierścienia A wyraźnie przeważają handel hurtowy i detaliczny oraz naprawy. $\mathrm{Na}$ drugim miejscu znajdują się: transport, gospodarka magazynowa i łączność (w gminie Masłów znajduje się lotnisko cywilno-sportowe), a następnie obsługa nieruchomości, wynajem i usługi związane z prowadzeniem działalności gospodarczej. W żadnej z gmin nie zanotowano obecności gospodarstw domowych zatrudniających pracowników ani organizacji i zespołów eksterytorialnych.

Ryc. 3. Wskaźnik przedsiębiorczości w gminach pierścienia A w latach 1995 i 2005

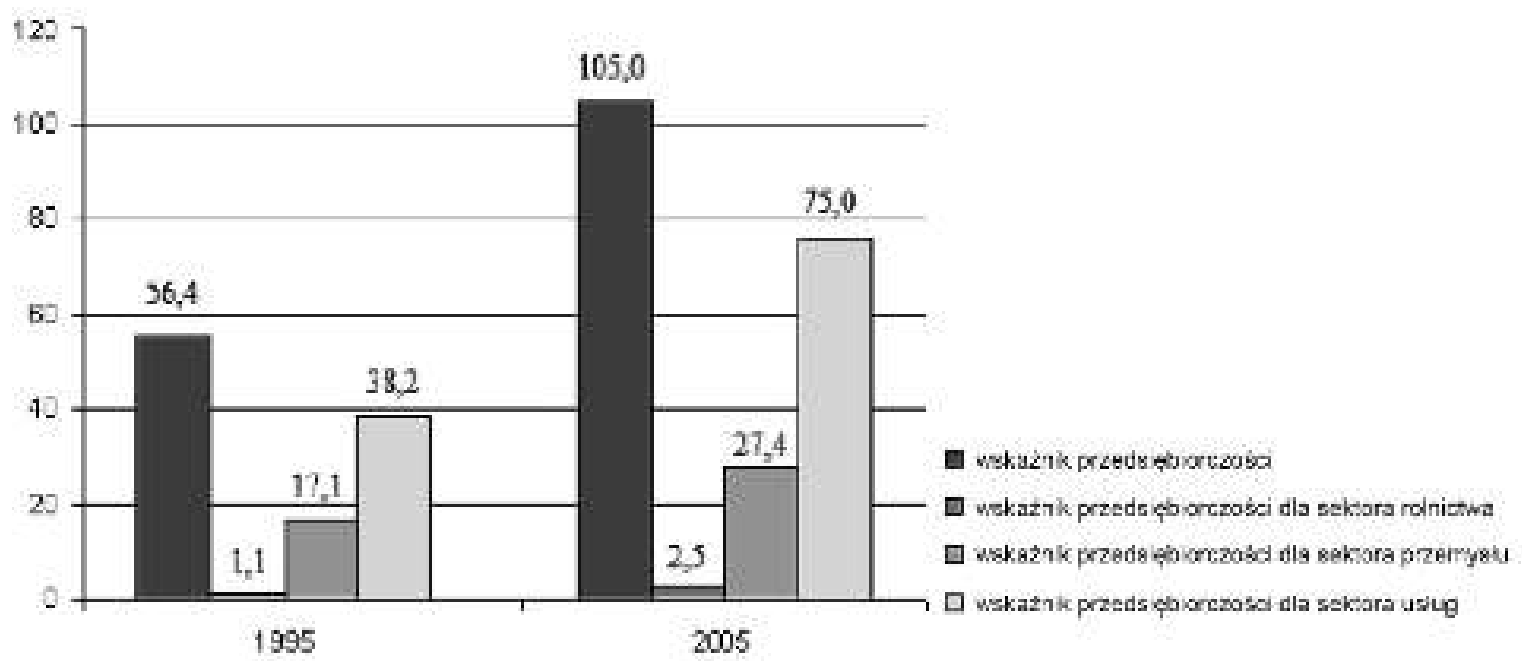

Źródło: opracowanie autorki na podstawie www.stat.gov.pl 
Podobnie wrastała wartość wskaźnika przedsiębiorczości dla sektora przemysłu: z 17,1 w 1995 r. do 27,4 w 2005 r. (czyli o 10,3). Analizując poziom przedsiębiorczości według sekcji PKD stwierdzono, że w gminach pierścienia A przeważają przetwórstwo przemysłowe i budownictwo (głównie ze względu na lokalizację kopalni kruszyw). Wrastała również - choć nieznacznie - wartość wskaźnika przedsiębiorczości dla sektora rolnictwa: z 1,1 w $1995 \mathrm{r}$. do 2,5 w 2005 r. (o 1,4).

W latach 1995-2005 w gminach pierścienia B również obserwuje się systematyczny wzrost wskaźnika przedsiębiorczości. W 1995 r. wynosił on 41,2, a w roku 2005 83,9, czyli o 42,7 więcej niż 10 lat wcześniej (tab. 7, ryc. 4).

W 1995 r. wskaźnik przedsiębiorczości dla sektora usług wynosił 31,2, a do 2005 r. jego wartość wzrosła o 29,9 (do 61,1). Wskaźnik rósł systematycznie w całym badanym okresie. Analizując poziom przedsiębiorczości według sekcji PKD zaobserwowano, że podobnie jak w gminach pierścienia A, w gminach pierścienia B wyraźnie przeważają: handel hurtowy i detaliczny oraz naprawy. Na drugim miejscu znajdują się: transport, gospodarka magazynowa i łączność oraz obsługa nieruchomości, wynajem i usługi związane z prowadzeniem działalności gospodarczej. Dużą grupę stanowi również sekcja PKD działalności usługowej, komunalnej i społecznej.

Ryc. 4. Wskaźnik przedsiębiorczości w gminach pierścienia B w latach 1995 i 2005

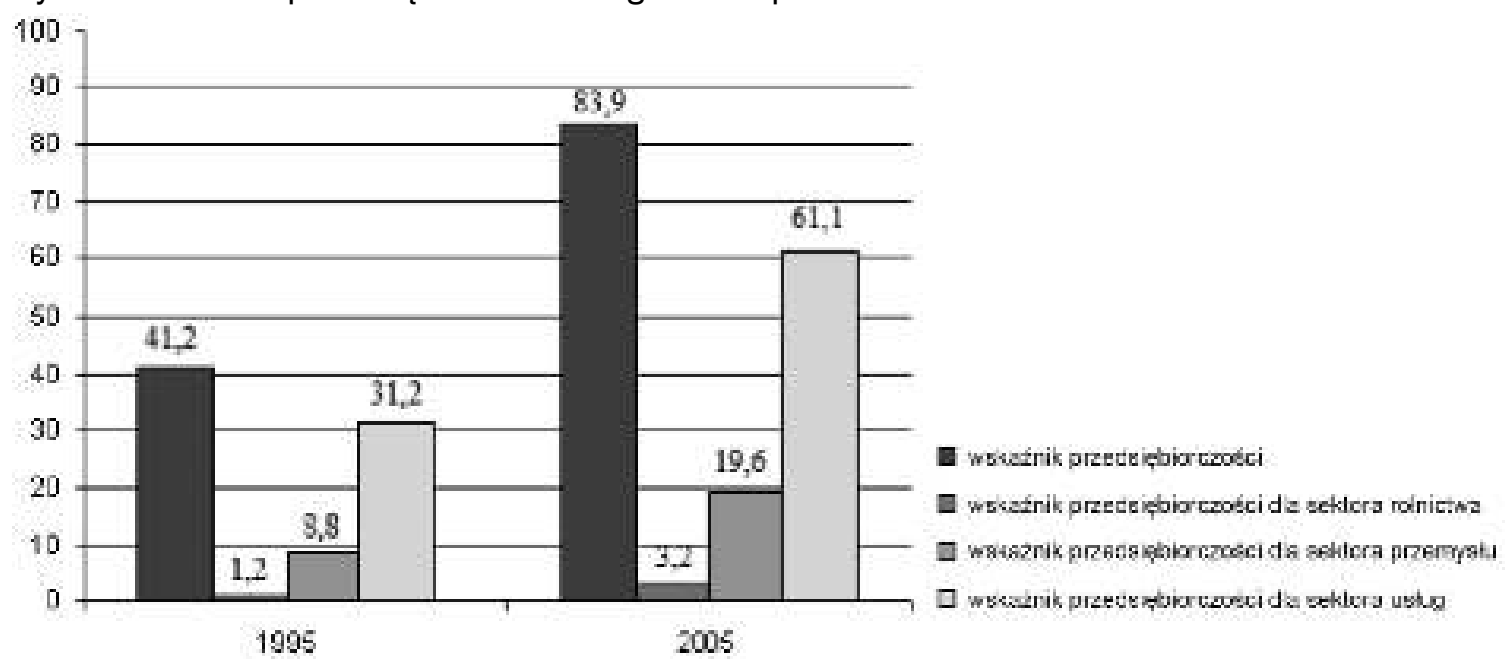

Źródło: opracowanie autorki na podstawie www.stat.gov.pl

W analizowanym okresie wrastały także wartości wskaźnika przedsiębiorczości dla sektora przemysłu: z 8,8 w 1995 r. do 19,6 w 2005 r. (czyli o 10,8). Biorąc pod uwagę sekcje PKD stwierdzono, że we wszystkich gminach pierścienia B (podobnie jak w gminach pierścienia A) przeważa przetwórstwo przemysłowe oraz budownictwo.

Niewielki wzrost (o 2,0 w stosunku do roku 1995) zaobserwowano również w wartościach wskaźnika przedsiębiorczości dla sektora rolnictwa, który z 1,2 w roku 1995 podniósł się do 3,2 w roku 2005. Rolnictwo w gminach pierścienia B, choć mało intensywne i niskotowarowe, jest zdecydowanie lepiej rozwinięte niż w gminach pierścienia A, głównie ze względu na fakt, że nie leżą one w bezpośrednim sąsiedztwie Kielc.

\section{Podsumowanie}

Porównując wskaźniki przedsiębiorczości w gminach pierścienia A i pierścienia B stwierdzono, że w całym analizowanym okresie wskaźnik przedsiębiorczości osiągał wyższe wartości w gminach pierścienia A: o 15,2 w roku 1995 i o 21,1 w roku 2005. W całym analizowanym 
okresie wskaźnik przedsiębiorczości w sektorze usług był większy w gminach pierścienia A: o 7,0 w 1995 r. oraz o 13,9 w 2005 r. Dysproporcje te zwiększały się z upływem lat. Wskaźnik przedsiębiorczości w sektorze przemysłu w całym okresie był większy w gminach pierścienia A: o 8,3 w 1995 r. i o 7,8 w 2005 r. Wskaźnik przedsiębiorczości w sektorze rolnictwa w analizowanym okresie osiągał wyższe wartości w gminach pierścienia B: o 0,1 w 1995 r. i o 0,7 w 2005 r.

Strefa podmiejska Kielc to obszar o dużym potencjale gospodarczym; lepiej wykorzystują go gminy pierścienia A, głównie ze względu na bliższe sąsiedztwo Kielc, a tym samym lepiej rozwiniętą infrastrukturę. Ponadto, na podstawie powyższej analizy oraz badań prowadzonych przez autorkę w strefie podmiejskiej Kielc (m.in. struktury użytkowania gruntów oraz struktury zatrudnienia) można stwierdzić, że jest to obszar wielofunkcyjny, przede wszystkim usługowo-przemysłowy, z przewagą handlu, budownictwa i przetwórstwa przemysłowego, a funkcja usługowa ulega w ostatnim czasie wzmocnieniu, o czym świadczy wzrost wskaźnika przedsiębiorczości w sektorze usług w latach 1995-2005. Bardzo silna jest również funkcja przemysłowa. Gminy te są silnie powiązane $\mathrm{z}$ miastem Kielce. Ponadto panują w nich sprzyjające warunki dla nowych lokalizacji i możliwości rozwoju, co stanowi impuls dla przemian funkcjonalnych i społeczno-ekonomicznych, prowadzących do intensyfikacji procesów suburbanizacji, wśród nich przenoszenie nadwyżki kapitału z nasyconych nimi terenów miasta (w tym podmiotów gospodarczych) na tereny jego zaplecza (Zioło 2008).

Gminy pierścienia B to również obszar, którego rozwój następuje w kierunku wielofunkcyjności, opartej przede wszystkim na sektorze usługowym z przewagą handlu i transportu, a funkcja usługowa ulega $\mathrm{w}$ ostatnim czasie wzmocnieniu, o czym świadczy wzrost wskaźnika przedsiębiorczości w sektorze usług w latach 1995-2005. Funkcja przemysłowa zaznacza się słabiej niż w gminach pierścienia A, bo choć wskaźnik przedsiębiorczości w sektorze przemysłu rośnie systematycznie, to jednak jest on niższy niż w gminach pierścienia A. Ponadto, zaobserwowano bardzo duży wzrost wskaźnika przedsiębiorczości w sektorze rolnictwa, co może wskazywać na fakt, że choć mało intensywne i niskotowarowe, jest ono dość dobrze rozwinięte.

Badania wykazały, że w polskiej gospodarce przedsiębiorczość jest fundamentem przekształceń społecznych i podstawowym czynnikiem dynamizującym wzrost oraz przeobrażenia strukturalne w okresie transformacji. Dlatego tak istotne staje się zrozumienie istoty przedsiębiorczości oraz analiza poszczególnych etapów jej rozwoju.

\section{Literatura}

1. Dziewoński K., 1987, Strefa podmiejska - próba ujęcia teoretycznego, „Przegląd Geograficzny”, z. $1-2$.

2. Jaremczuk K., 2003, Uwarunkowania rozwoju przedsiębiorczości-szanse i zagrożenia, Wydawnictwo PWSZ, Tarnobrzeg.

3. Jelonek A., 1985, O problemach demograficznych strefy podmiejskiej, „Acta Universitatis Lodziensis”, Folia Geographica, nr 5, Łódź.

4. Jurek J., 1991, Zmiany struktury społeczno-ekonomicznej wsi w strefie podmiejskiej Poznania, UAM, seria Geografia, nr 52, Poznań.

5. Kaliszczak L., 2002, Źródła sukcesu małych i średnich przedsiębiorstw $w$ warunkach zmiennego otoczenia [w:] Uwarunkowania sukcesu przedsiębiorstwa, J. Targalski (red.), Wydawnictwo Akademii Ekonomicznej w Krakowie, Kraków.

6. Koter M., 1985, Ksztaltowanie się strefy podmiejskiej w świetle badań historyczno-geograficznych, „Acta Universitatis Lodziensis”, „Folia Geographica”, nr 5, Łódź.

7. Lichtarski J., 2003, Podstawy nauki o przedsiębiorstwie, Wydawnictwo AE we Wrocławiu, Wrocław. 
8. Liszewski S., 1985, Funkcja przemysłowa strefy podmiejskiej Łodzi [w:] Struktura i przemiany stref podmiejskich dużych miast, „Folia Geographica”, nr 5.

9. Maik W., 1985, Charakterystyka strefy podmiejskiej w kategoriach funkcjonalnych, „Acta Universitatis Lodziensis”, „Folia Geographica”, nr 5, Łódź.

10. Maik W., 1997, Geografia osadnictwa, ludności i turyzmu wobec transformacji systemowej, UMK, Toruń.

11. Misiak W., 1992, Miasta polskie w okresie przemian; studia nad Wrocławiem i Oleśnica, Wydawnictwo Uniwersytetu Wrocławskiego, Wrocław.

12. Przedsiębiorczość i rozwój firmy, 1999, J. Targalski (red.), Wydawnictwo Akademii Ekonomicznej w Krakowie, Kraków.

13. Rajman J., 2000, Geografia ludności i osadnictwa, Wydawnictwo Naukowe Akademii Pedagogicznej, Kraków.

14. Rakowski W., 1985, Urbanizacja stref podmiejskich, „Acta Universitatis Lodziensis”, „Folia Geographica", nr 5, Łódź.

15. Rocznik Statystyczny Województwa Kieleckiego 1996, WUS, Kielce.

16. Rocznik Statystyczny Województwa Świętokrzyskiego 2006, US, Kielce.

17. Straszewicz L., 1985, Strefa podmiejska: pojęcia i definicje, „Acta Universitatis Lodziensis”, „Folia Geographica", nr 5, Łódź.

18. Suliborski A., 1985, Delimitacja strefy podmiejskiej Łodzi. Analiza pojęć i założeń metodologicznych, „Acta Universitatis Lodziensis”, „Folia Geographica”, nr 5, Łódź.

19. Ziemilski A., Skórzyński Z., 1983, Strefy podmiejskie w świadomości potocznej [w:] Kształtowanie krajobrazu stref podmiejskich, SGGW - AR, Warszawa.

20. Zioło Z., 2008, Renesans badań nad procesami semiurbanizacji [w:] Obszary urbanizacji i semiurbanizacji wsi polskiej a możliwości ich rozwoju w ramach PROW 2007-2013, T. Markowski, Z. Strzelecki (red.), PAN, Warszawa.

21. www.stat.gov.pl

\section{Entrepreneurship Development in Suburban Area of Kielce in the Conditions of Economic Transformation}

The aim of this project is to analyze the entrepreneurship development in suburban area of Kielce in the period 1995-2005. Eight communes adjacent to Kielce city (in the project called "the A ring") and fourteen communes that surround the eight former ("the B ring") were analyzed. The analysis shows that suburban area of Kielce has the multifunctional feature and the highest growth rate were noted in services (commerce, construction, processing) and in industry. As for the spatial system the highest growth rate were reached by the communes from "A ring". Average indicator of entrepreneurship was 56.4 in 1995, and 105.0 in 2005. In the "B ring" indicator of entrepreneurship was 41.2 in 1995 and 83,9 in 2005. 